Hydrol. Earth Syst. Sci., 14, 2003-2010, 2010

www.hydrol-earth-syst-sci.net/14/2003/2010/

doi:10.5194/hess-14-2003-2010

(C) Author(s) 2010. CC Attribution 3.0 License.

\title{
Irrigation enhances precipitation at the mountains downwind
}

\author{
J. Jódar, J. Carrera, and A. Cruz \\ GHS, IDAEA, CSIC, Jordi Girona 18, 08034 Barcelona, Spain
}

Received: 30 April 2010 - Published in Hydrol. Earth Syst. Sci. Discuss.: 20 May 2010

Revised: 30 September 2010 - Accepted: 7 October 2010 - Published: 22 October 2010

\begin{abstract}
Atmospheric circulation models predict an irrigation-rainfall feedback. However, actual field evidences for local evaporation recycling (moisture feedback) are weak. We present strong field evidence for an increase in rainfall at the mountains located downwind of irrigated zones. We chose two regions, located in semiarid southern Spain, where irrigation started at a well defined date, and we analyzed rainfall statistics before and after the beginning of irrigation. Analyzed statistics include the variation of (1) mean rainfall $\Delta P,(2)$ ratio of monthly precipitation to annual precipitation $\Delta r$, and (3) number of months with noticeable rainfall episodes $\Delta P_{\min }$ after a shifting from unirrigated to irrigated conditions. All of them show statistically significant increases. $\Delta P$ and $\Delta r$ show larger and more statistically significant variations in June and July than in August. They also tend to increase with the annual volume of water applied in the neighbouring upwind irrigation lands. Increases in $\Delta P_{\min }$ are statistically significant during the whole summer. That is, the number of noticeable rainfall events displays a relevant increase after irrigation. In fact, it is this number, rather than sporadic large rainfall episodes what makes the summers wetter. The increase in rainfall, while statistically significant, is distributed over a broad region, so that it is of little relevance from a water resources perspective, although it may enhance vegetation yield.
\end{abstract}

\section{Introduction}

Irrigation-precipitation feedback may play an important role in modulating changes in the hydrologic cycle at different scales. Irrigation represents arguably the most dramatic landuse change from the perspective of rainfall (Pielke et al., 2007). The net addition of water moisture to the air in the

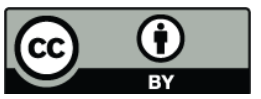

Correspondence to: J. Jódar

(jorge.jodar@idaea.csic.es) boundary layer due to evaporation triggers convection, and should be reflected in a net increase of rainfall, during the irrigation season.

Theoretical and modelling studies indeed predict that irrigation may cause a variation in rainfall due to the soil moisture-atmosphere interactions. A few studies have found that local recycling of evaporated moisture is not important when compared to large scale moisture fluxes (Giorgi et al., 1996; Paegle et al., 1996). In fact, very dry soil conditions may favour increases in rainfall (i.e., negative soil moisture feedback). However, a far larger number of studies and model experiments support positive moisture feedback (e.g. Eltahir, 1998; Zheng and Eltahir, 1998; Boucher et al., 2004; Guo et al., 2006; to name some of them). Furthermore, Atmospheric General Circulation Models (AGCMs) have predicted the existence of regional "hot spot" feedback zones, regions that concentrate moisture feedback. This is manifested in precipitation during the boreal summer (June through August) in the Great Plains of North America, the Sahel, equatorial Africa and India (Koster et al., 2004). All AGCMs predict variations in rainfall as a net result of the irrigation-precipitation feedback. However, they also show a great deal of variation, both in terms of patterns and the overall strength of feedback. That is, model simulation outputs are highly variable and uncertain. The uncertainty might be reduced if the feedback was properly characterized by field measurements (Koster et al., 2006).

Despite of the above results, actual field evidences supporting irrigation-rainfall feedback are surprisingly weak. Earliest studies were performed at the Columbia River basin. Stidd (1975) found an increase in rainfall not only downwind but also upwind of irrigation fields, while Fowler and Helvey (1974) found no evidence of feedback. The traditional reference for feedback is the work of Barnston and Schickedanz (1984) who found an increase in precipitation associated to nearby irrigated lands in the Texas Panhandle region of the Great Plains over the time period of 1931-1970. The result was obtained by a principal component analysis of

Published by Copernicus Publications on behalf of the European Geosciences Union. 
warm-season precipitation and irrigation data. Nevertheless, Moore and Rojstaczer (2001) performed the same principal component analysis for the same region over a different time period (1948 to 1997) and found no statistically significant evidence for a consistent irrigation effect in the monthly precipitation data. Moore and Rojstaczer (2002) revisited the Texas Panhandle region, analysing precipitation patterns in the summer months of 1996 and 1997. In their study no distinct spatial trends in precipitation intensity were observed either. Nevertheless, they observed that storms show larger coherence and size within an "anomaly area" about $90 \mathrm{~km}$ downwind of the irrigation area, indicating elongated storms, greater storm duration, or both. Unfortunately, the duration of the observation interval is too short and the impact too far away to draw a strong conclusion.

Our conjecture is that the feedback should concentrate in the mountains downwind the irrigation fields because the adiabatic cooling of moist air caused by upwards flow should promote condensation and rainfall (Smith, 1979; Smith et al., 1997; Lin et al., 2001). The objective of this paper is to test the above conjecture at two areas, where rainfall records are available both before and after the beginning of irrigation.

\section{Methods}

\subsection{Study zones}

The main premise of the study is that irrigation in the plains causes an increase in summer precipitation at the adjacent downwind mountains. Therefore, we sought irrigation areas meeting the following requirements:

a. Located in semiarid watersheds.

b. Undergo a well defined change from unirrigated to heavily irrigated conditions.

c. Availability of weather stations with long rainfall records located at the downwind (mean summer wind direction) adjacent mountains (see Fig. 1).

d. Display a homogeneous irrigation scheme (i.e., similar temporal distribution of irrigation water volumes for the whole area) with a high irrigation water demand in summer.

We found two irrigation areas meeting these requirements: (1) Upper and Lower Vegas (ULV), and (2) Lower Guadalquivir (LG). These zones are separated by the Sierra Morena range, which stretches for $400 \mathrm{~km}$ East-West across southern Spain, forming the border of the central plateau (Meseta Central) of Iberia, and acting as a divide between the valleys of the Guadiana River to the north and the Guadalquivir River to the south.

The ULV irrigated land is located in the province of Badajoz, along the main course of the Guadiana River (Fig. 1).

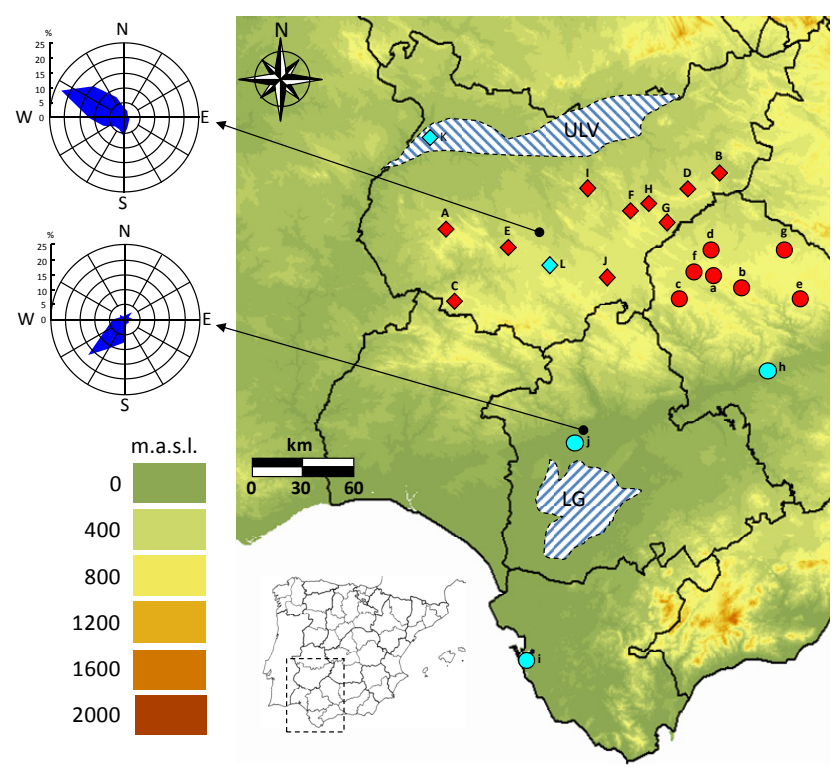

Fig. 1. Map of the study areas showing the location of the Upper and Lower Vegas (ULV), and Lower Guadalquivir (LG) irrigation lands (IL) and their corresponding summer wind rose. Diamond and circle symbols mean ULV and LG meteorological stations, respectively. Red symbols stand for meteorological stations located in mountains downwind the IL. Light blue symbols correspond to reference meteorological stations located in the plains. The alphabetical codes used to identify the meteorological stations are provided in Tables 1,2 and 3.

Irrigation started in 1963, as part of the "Badajoz" regional development plan. Several reservoirs were built in the Guadiana River and its main tributaries. Additionally, a dense irrigation network was set up. Access to large volumes of surface water became easy and traditional agriculture changed to intensive farming in the region along time, following the field implementation of the different measures considered in the development plan. These measures were officially completed in 1976. Some 121000 ha are irrigated nowadays with an endowment of $8500 \mathrm{~m}^{3} / \mathrm{ha} / \mathrm{yr}$, giving a mean annual irrigation volume of $1.028 \times 10^{9} \mathrm{~m}^{3}$. The predominant wind direction during the summer is from northwest (Font and I. N. M., 1983), as the Atlantic air flows towards the north side of Sierra Morena and its minor ranges that run transversely from NW to SE (i.e. mountain ranges of Monsalud, Rinconada or Tudia to name a few). We have selected 11 meteorological stations (all that have long rainfall records) located in these minor mountains ranges (dark red rhombus in Fig. 1). Additionally, two meteorological stations located in the plains surrounding the irrigation land will be used as reference stations (light blue rhombus). One of them (station L, Usagres) is located downwind and the other (station K, Badajoz) is located upwind of the irrigation area.

The LG irrigated land belongs to the lower part of the Guadalquivir River Basin where traditional agriculture had been practiced for hundreds of years on small plots and 


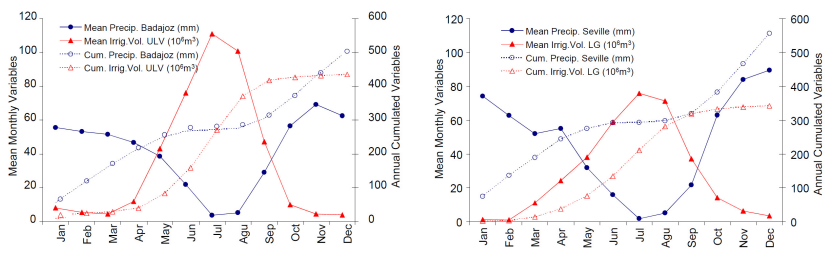

Fig. 2. Monthly distribution of precipitation and applied Irrigation Volumes in the Upper and lower Vegas (left) and the Lower Guadalquivir irrigation land (right). Solid symbols refer to the variables and empty symbols to their corresponding cumulated value. The averaging period for precipitation goes from 1890 to 2001 in the ULV, and from 1951 to 2001 in the LG. The averaging period for irrigation volume goes from 1963 to 2001 in the ULV, and from 1971 to 2001 in the LG.

overall small volumes of water. The irrigated land is located on the left side of the river, close to the city of Seville (Fig. 1). Here irrigation started in 1971 over a surface of some 60000 ha, with a mean endowment of $9300 \mathrm{~m}^{3} / \mathrm{ha} / \mathrm{yr}$, yielding a mean annual irrigation volume of $0.558 \times 10^{9} \mathrm{~m}^{3}$ of surface water. The latter represents half of the irrigation water volume applied in ULV. Wind blows predominantly from the southwest during the summer (Font and I. N. M., 1983), partly because of the geography and proximity of the Guadalquivir River (Robinson, 1984). This wind direction carries irrigation moisture towards the minor ranges that run the south face of Sierra Morena from NW to SE transversely (i.e. mountain ranges of Castillo, Cabras, and Alcudia among others). Long rainfall records are available at 7 meteorological located in these mountains downwind of the irrigation lands (dark red circles in Fig. 1). Three reference stations (light blue circles) have been selected in the valley. Two of them (stations j, Seville, and h, Cordoba) are located downwind and one (station i, San Fernando) is located upwind of the irrigation area.

Both areas can be considered semiarid with annual rainfall hardly reaching $550 \mathrm{~mm}$ and potential evaporation close to $1000 \mathrm{~mm}$. Irrigation demand in both areas concentrates during the summer, which is very dry (Fig. 2).

\subsection{Statistical analysis}

Preliminary inspection of the observed meteorological data provides some evidences that summer rainfall has changed after irrigation in terms of both occurrence (Fig. 3) and volume (Fig. 4):

Temporal evolution of precipitation during the irrigation months (June, July and August) displays a clear difference between a reference meteorological station (Badajoz_K), and Barcarrota_A, which is located in the mountains downwind the ULV irrigation land (Fig. 3). The frequency of dry months looks unaffected by the beginning of irrigation at the reference station. However, a clear decrease in the frequency
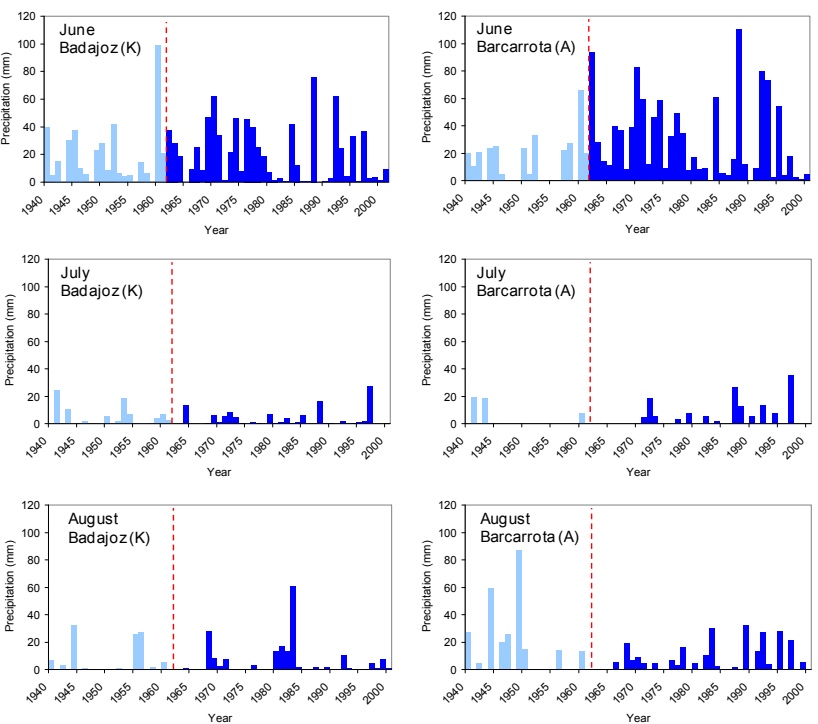

Fig. 3. Temporal evolution of the cumulated precipitation for the months of June, July and August, measured in both, the reference meteorological station of Badajoz_K (left), and the meteorological station of Barcarrota_A (right), which is located in the adjacent mountains downwind ULV. The dashed red line indicates the beginning of the irrigation period.

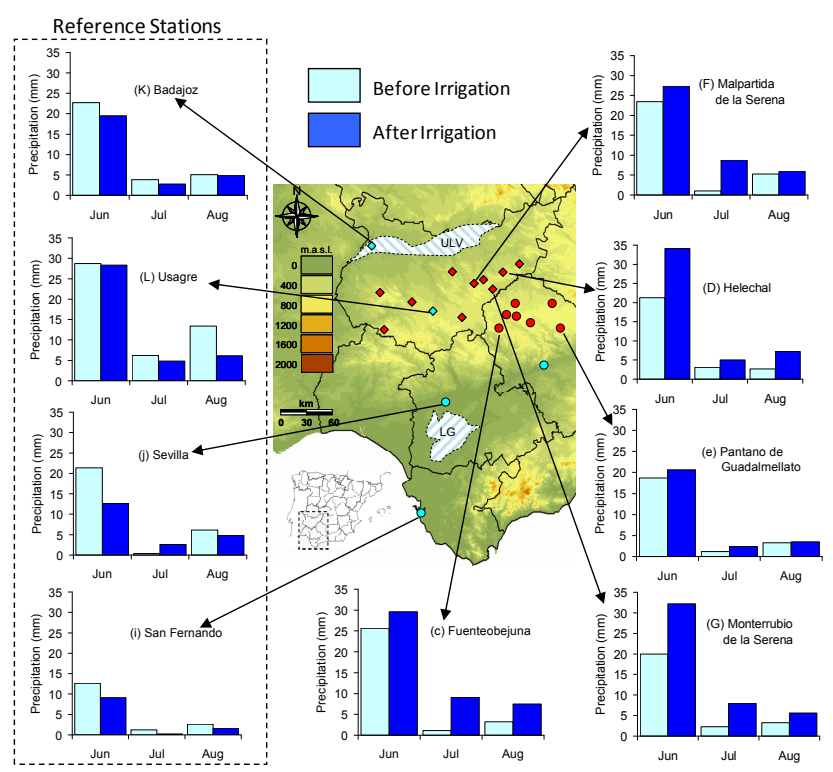

Fig. 4. Mean summer (June, July and August) precipitation before (light blue) and after (dark blue) the beginning of the irrigation period for some reference stations (left side inside the dashed box) and other measuring points located in the mountains downwind of the ULV and LG irrigation areas. 
Table 1. Monthly averaged values of precipitation before $\left(P_{1}\right)$ and after $\left(P_{2}\right)$ the Beginning of the Irrigation Period (BIP), and precipitation increment $\Delta P$ with respect to $P_{1}$, measured in the meteorological stations located in the mountains downwind of irrigation land (MSs) and reference meteorological stations (RSs) for both the Upper and Lower Vegas (ULV) and the Lower Guadalquivir (LG) irrigation lands. NB and NA stand for the number of meteorological stations with available data used in the analysis before and after the BIP, respectively. Code is the meteorological station identifying letter used in Fig. 1. Grey shaded cell means that the variation is statistically significant.

\begin{tabular}{|c|c|c|c|c|c|c|c|c|c|c|c|}
\hline & \multirow[b]{2}{*}{ Code } & \multirow[b]{2}{*}{ (NB/NA) } & \multicolumn{3}{|c|}{$P_{1}(\mathrm{~mm})$} & \multicolumn{3}{|c|}{$P_{2}(\mathrm{~mm})$} & \multicolumn{3}{|c|}{$\Delta P(\%)=\left(P_{2}-P_{1}\right) / P_{1}$} \\
\hline & & & June & July & August & June & July & August & June & July & August \\
\hline \multicolumn{12}{|l|}{ ULV MSs } \\
\hline Barcarrota & A & $(24 / 37)$ & 17.7 & 1.9 & 11.1 & 28.0 & 3.9 & 7.0 & $58 \%$ & $105 \%$ & $-37 \%$ \\
\hline Cabeza del Buey & $\mathrm{B}$ & $(25 / 35)$ & 23.7 & 4.6 & 5.9 & 30.2 & 9.2 & 5.7 & $27 \%$ & $100 \%$ & $-3 \%$ \\
\hline Fregenal de la Sierra & $\mathrm{C}$ & $(17 / 38)$ & 19.9 & 2.7 & 13.5 & 24.2 & 6.2 & 6.5 & $22 \%$ & $130 \%$ & $-52 \%$ \\
\hline Helechal & $\mathrm{D}$ & $(14 / 34)$ & 21.3 & 3.1 & 2.7 & 34.1 & 5.0 & 7.2 & $60 \%$ & $61 \%$ & $167 \%$ \\
\hline Los Santos de Maimona & $\mathrm{E}$ & $(19 / 34)$ & 17.2 & 5.1 & 6.4 & 24.3 & 8.0 & 3.7 & $41 \%$ & $57 \%$ & $-42 \%$ \\
\hline Malpartida de la Serena & $\mathrm{F}$ & $(14 / 38)$ & 23.4 & 1.0 & 5.3 & 27.3 & 8.7 & 6.0 & $17 \%$ & $770 \%$ & $13 \%$ \\
\hline Monterrubio de la Serena & $\mathrm{G}$ & $(14 / 39)$ & 20.0 & 2.3 & 3.3 & 32.2 & 8.0 & 5.6 & $61 \%$ & $248 \%$ & $70 \%$ \\
\hline Puerto Hurraco & $\mathrm{H}$ & $(20 / 38)$ & 22.3 & 4.5 & 4.2 & 32.3 & 8.4 & 11.8 & $45 \%$ & $87 \%$ & $181 \%$ \\
\hline Valle Serena & $\mathrm{I}$ & $(14 / 39)$ & 18.1 & 2.6 & 4.2 & 20.9 & 7.2 & 5.7 & $15 \%$ & $177 \%$ & $36 \%$ \\
\hline Valverde de Llerena & $\mathrm{J}$ & $(18 / 37)$ & 15.2 & 5.3 & 3.6 & 28.7 & 3.4 & 3.3 & $89 \%$ & $-36 \%$ & $-8 \%$ \\
\hline Monthly Mean value & & & 19.9 & 3.3 & 6.0 & 28.2 & 6.8 & 6.3 & $43.5 \%$ & $169.9 \%$ & $32.4 \%$ \\
\hline \multicolumn{12}{|l|}{ ULV RSs } \\
\hline Badajoz & $\mathrm{K}$ & $(73 / 39)$ & 22.7 & 3.8 & 5.1 & 19.5 & 2.8 & 4.9 & $-14.1 \%$ & $-26.3 \%$ & $-3.9 \%$ \\
\hline Usagre & $\mathrm{L}$ & $(23 / 39)$ & 28.7 & 6.2 & 13.4 & 28.3 & 4.8 & 6.1 & $-1.4 \%$ & $-22.6 \%$ & $-54.5 \%$ \\
\hline Monthly Mean value & & & 25.7 & 5.0 & 9.3 & 23.9 & 3.8 & 5.5 & $-7.7 \%$ & $-24.4 \%$ & $-29.2 \%$ \\
\hline \multicolumn{12}{|l|}{ LG MSs } \\
\hline Bélmez & a & $(26 / 28)$ & 23.9 & 3.8 & 7.6 & 27.6 & 5.6 & 5.5 & $15.5 \%$ & $47.4 \%$ & $-27.6 \%$ \\
\hline Espiel & $\mathrm{b}$ & $(24 / 29)$ & 23.0 & 1.9 & 7.2 & 24.5 & 7.3 & 6.4 & $6.5 \%$ & $284.2 \%$ & $-11.1 \%$ \\
\hline Fuenteobejuna & $\mathrm{c}$ & $(26 / 31)$ & 25.6 & 1.1 & 3.2 & 29.6 & 9.1 & 7.5 & $15.6 \%$ & $727.3 \%$ & $134.4 \%$ \\
\hline Hinojosa del Duque & $\mathrm{d}$ & $(28 / 28)$ & 21.7 & 4.2 & 7.3 & 25.8 & 10.2 & 5.4 & $18.9 \%$ & $142.9 \%$ & $-26.0 \%$ \\
\hline Pantano Guadalmellato & $\mathrm{e}$ & $(56 / 23)$ & 18.7 & 1.2 & 3.3 & 20.6 & 2.4 & 3.5 & $10.2 \%$ & $100.0 \%$ & $6.1 \%$ \\
\hline Peñarroya & $\mathrm{f}$ & $(53 / 9)$ & 23.2 & 3.5 & 5.4 & 29.5 & 1.7 & 13.2 & $27.2 \%$ & $-51.4 \%$ & $144.4 \%$ \\
\hline Pozoblanco & $\mathrm{g}$ & $(48 / 29)$ & 28.6 & 4.6 & 6.7 & 29.5 & 10.2 & 5.4 & $3.1 \%$ & $121.7 \%$ & $-19.4 \%$ \\
\hline Monthly Mean value & & & 23.5 & 2.9 & 5.8 & 26.7 & 6.6 & 6.7 & $13.9 \%$ & $196.0 \%$ & $28.7 \%$ \\
\hline \multicolumn{12}{|l|}{ LG RSs } \\
\hline Córdoba & $\mathrm{h}$ & $(15 / 23)$ & 24.5 & 4.4 & 2.7 & 18.7 & 3.1 & 2.8 & $-24 \%$ & $-30 \%$ & $4 \%$ \\
\hline San Fernando & $\mathrm{i}$ & $(108 / 23)$ & 12.6 & 1.2 & 2.6 & 9.1 & 0.2 & 1.6 & $-28 \%$ & $-83 \%$ & $-38 \%$ \\
\hline Sevilla & $\mathrm{j}$ & $(23 / 27)$ & 21.4 & 0.4 & 6.1 & 12.6 & 2.6 & 4.8 & $-41 \%$ & $550 \%$ & $-21 \%$ \\
\hline Monthly Mean value & & & 19.5 & 2.0 & 3.8 & 13.5 & 2.0 & 3.1 & $-31 \%$ & $146 \%$ & $-19 \%$ \\
\hline
\end{tabular}

of dry months can be observed at Barcarrota_A, especially after 1976.

Figure 4 displays the mean monthly precipitation for June, July and August, before and after the beginning of the irrigation period, at both reference and mountains downwind stations. Reference stations show a slight decrease, whereas rainfall volume tends to increase at meteorological stations located in the mountains downwind of the irrigation lands.

In view of these observations, three different statistics will be analyzed:

1. Change of mean monthly rainfall, $\Delta P$.

2. Change in the ratio of summer to annual precipitation, $\Delta r$, to test is concentrated during irridation season.
3. Change in the number of noticeable rainfall episodes (i.e. days with total rainfall above $2 \mathrm{~mm}$ ), $\Delta P_{\min }$, to test variations are caused by a few high intensity events.

We tested whether the means of $P$ and $r$ differ statistically between the periods before and after irrigation using a standard t_test (O'Mahony, 1986; Moore, 1995; Spiegel and Stephens, 1999; to name a few) and a 95\% confidence level for the two statistics. The analysis of $P_{\min }$ is based on comparing the frequency of noticeable rainfall episodes (i.e. days with total rainfall above $2 \mathrm{~mm}$ ) before and after the beginning of the irrigation. 
Table 2. Monthly to annual precipitation ratio before $\left(r_{1}\right)$ and after $\left(r_{2}\right)$ the Beginning of the Irrigation Period (BIP), and ratio increment $\Delta r$ with respect to $r_{1}$, measured in the meteorological stations located in the mountains downwind of irrigation land (MSs) and reference meteorological stations (RSs) for both the Upper and Lower Vegas (ULV) and the Lower Guadalquivir (LG) irrigation lands. NB and NA stand for the number of meteorological stations with available data used in the analysis before and after the BIP, respectively. Code is the meteorological station identifying letter used in Fig. 1. Grey shaded cell means that the variation is statistically significant.

\begin{tabular}{|c|c|c|c|c|c|c|c|c|c|c|c|}
\hline & \multirow[b]{2}{*}{ Code } & \multirow[b]{2}{*}{ (NB/NA) } & \multicolumn{3}{|c|}{$r_{1}(-)$} & \multicolumn{3}{|c|}{$r_{2}(-)$} & \multicolumn{3}{|c|}{$\Delta r(\%)=\left(r_{2}-r_{1}\right) / r_{1}$} \\
\hline & & & June & July & August & June & July & August & June & July & August \\
\hline \multicolumn{12}{|l|}{ ULV MSs } \\
\hline Barcarrota & A & $(24 / 37)$ & 2.4 & 0.2 & 2.2 & 4.9 & 0.6 & 1.2 & $104.2 \%$ & $200.0 \%$ & $-45.5 \%$ \\
\hline Cabeza del Buey & $\mathrm{B}$ & $(25 / 35)$ & 5.0 & 1.0 & 0.8 & 6.9 & 1.6 & 0.9 & $38.0 \%$ & $60.0 \%$ & $12.5 \%$ \\
\hline Fregenal de la Sierra & $\mathrm{C}$ & $(17 / 38)$ & 2.8 & 0.4 & 2.1 & 4.0 & 0.9 & 1.2 & $42.9 \%$ & $125.0 \%$ & $-42.9 \%$ \\
\hline Helechal & $\mathrm{D}$ & $(14 / 34)$ & 4.2 & 0.6 & 0.4 & 7.0 & 0.9 & 1.4 & $66.7 \%$ & $50.0 \%$ & $250.0 \%$ \\
\hline Los Santos de Maimona & $\mathrm{E}$ & $(19 / 34)$ & 2.9 & 1.0 & 1.1 & 5.6 & 1.4 & 0.9 & $93.1 \%$ & $40.0 \%$ & $-18.2 \%$ \\
\hline Malpartida de la Serena & $\mathrm{F}$ & $(14 / 38)$ & 3.8 & 0.2 & 1.1 & 6.3 & 1.4 & 1.3 & $65.8 \%$ & $600.0 \%$ & $18.2 \%$ \\
\hline Monterrubio de la Serena & $\mathrm{G}$ & $(14 / 39)$ & 3.4 & 0.4 & 0.6 & 6.6 & 1.3 & 1.0 & $94.1 \%$ & $225.0 \%$ & $66.7 \%$ \\
\hline Puerto Hurraco & $\mathrm{H}$ & $(20 / 38)$ & 3.4 & 1.0 & 1.0 & 7.3 & 1.2 & 1.8 & $114.7 \%$ & $20.0 \%$ & $80.0 \%$ \\
\hline Valle Serena & $\mathrm{I}$ & $(14 / 39)$ & 4.0 & 0.5 & 1.1 & 5.7 & 1.4 & 1.4 & $42.5 \%$ & $180.0 \%$ & $27.3 \%$ \\
\hline Valverde de Llerena & $\mathrm{J}$ & $(18 / 37)$ & 2.6 & 0.9 & 0.6 & 5.7 & 0.6 & 0.7 & $119.2 \%$ & $-33.3 \%$ & $16.7 \%$ \\
\hline Monthly Mean value & & & 3.5 & 0.6 & 1.1 & 6.0 & 1.1 & 1.2 & $78.1 \%$ & $146.7 \%$ & $36.5 \%$ \\
\hline \multicolumn{12}{|l|}{ ULV RSs } \\
\hline Badajoz & $\mathrm{K}$ & $(73 / 39)$ & 4.3 & 0.7 & 1.0 & 4.2 & 0.5 & 1.1 & $-2.3 \%$ & $-28.6 \%$ & $10.0 \%$ \\
\hline Usagre & $\mathrm{L}$ & $(23 / 39)$ & 4.0 & 0.9 & 2.3 & 5.1 & 0.8 & 1.3 & $27.5 \%$ & $-11.1 \%$ & $-43.5 \%$ \\
\hline Monthly Mean value & & & 4.2 & 0.8 & 1.7 & 4.7 & 0.7 & 1.2 & $12.6 \%$ & $-19.8 \%$ & $-16.7 \%$ \\
\hline \multicolumn{12}{|l|}{ LG MSs } \\
\hline Bélmez & $\mathrm{a}$ & $(26 / 28)$ & 4.3 & 0.5 & 1.1 & 5.7 & 0.9 & 0.9 & $32.6 \%$ & $80.0 \%$ & $-18.2 \%$ \\
\hline Espiel & $\mathrm{b}$ & $(24 / 29)$ & 4.1 & 0.2 & 1.0 & 4.8 & 1.1 & 1.1 & $17.1 \%$ & $450.0 \%$ & $10.0 \%$ \\
\hline Fuenteobejuna & $\mathrm{c}$ & $(26 / 31)$ & 4.9 & 0.1 & 0.9 & 6.4 & 1.6 & 1.5 & $30.6 \%$ & $1500.0 \%$ & $66.7 \%$ \\
\hline Hinojosa del Duque & $\mathrm{d}$ & $(28 / 28)$ & 5.4 & 1.1 & 1.5 & 6.2 & 2.2 & 1.2 & $14.8 \%$ & $100.0 \%$ & $-20.0 \%$ \\
\hline Pantano Guadalmellato & $\mathrm{e}$ & $(56 / 23)$ & 2.7 & 0.2 & 0.4 & 3.7 & 0.3 & 0.5 & $37.0 \%$ & $50.0 \%$ & $25.0 \%$ \\
\hline Peñarroya & $\mathrm{f}$ & $(53 / 9)$ & 4.6 & 0.6 & 1.0 & 7.4 & 0.4 & 1.7 & $60.9 \%$ & $-33.3 \%$ & $70.0 \%$ \\
\hline Pozoblanco & $\mathrm{g}$ & $(48 / 29)$ & 5.7 & 0.7 & 1.2 & 5.8 & 1.8 & 1.1 & $1.8 \%$ & $157.1 \%$ & $-8.3 \%$ \\
\hline $\begin{array}{l}\text { Monthly Mean value } \\
\text { LG RSs }\end{array}$ & & & 4.5 & 0.5 & 1.0 & 5.7 & 1.2 & 1.1 & $27.8 \%$ & $329.1 \%$ & $17.9 \%$ \\
\hline Córdoba & $\mathrm{h}$ & $(15 / 23)$ & 3.5 & 0.6 & 0.3 & 3.4 & 0.4 & 0.4 & $-2.9 \%$ & $-33.3 \%$ & $33.3 \%$ \\
\hline San Fernando & $\mathrm{i}$ & $(108 / 23)$ & 2.1 & 0.2 & 0.5 & 2.0 & 0.1 & 0.4 & $-4.8 \%$ & $-75.0 \%$ & $-20.0 \%$ \\
\hline Sevilla & $\mathrm{j}$ & $(23 / 27)$ & 3.3 & 0.1 & 0.7 & 2.7 & 0.3 & 1.0 & $-18.2 \%$ & $200.0 \%$ & $42.9 \%$ \\
\hline Monthly Mean value & & & 3.0 & 0.3 & 0.5 & 2.7 & 0.3 & 0.6 & $-8.6 \%$ & $30.6 \%$ & $18.7 \%$ \\
\hline
\end{tabular}

\section{Results}

Tables 1, 2 and 3 summarise results of the three statistics for ULV and LG irrigation lands. These tables provide the mean values of the three statistics for every meteorological station, highlighting statistically significant increments. Additionally, monthly mean values of the statistics are provided by grouping reference stations (RSs), and stations located in the mountains downwind of irrigation land (MSs).

Simple inspection of these tables reveals a different behaviour of MSs and RSs. Mean values tend to increase at the former, but decrease at the latter. This result suggests that irrigation affects the way it rains in the neighbouring downwind mountains, probably modifying the synoptic climate structure and trend at the local scale.
The mean rainfall at MSs in ULV shows a common positive change in June and July (Table 1). In August, the general trend in $\Delta P$ is ambiguous, even showing statistical significant decreases in the meteorological stations of Barcarrota, Freguenal de la Sierra and Santos de Maimona. Analogously, the variation at MSs in LG also implies rainfall increases during June and July, and an unclear trend in August. Nevertheless, variations at LG do not have the same statistical significance as in the case of ULV. The difference might be explained by the smaller irrigation surface, and applied irrigation volume in the lower Guadalquivir irrigation land. After the beginning of the irrigation period, $\Delta P$ shows an almost general positive variation in the meteorological stations located in the mountains downwind of both irrigation lands ( $83 \%$ and $76 \%$ cases in ULV and LG, respectively). The 
Table 3. Percentage of noticeable rainfall episodes (i.e. days with total rainfall above $2 \mathrm{~mm}$ ) respect to the total rainfall episodes registered before $\left(P_{\min 1}\right)$ and after $\left(P_{\min 2}\right)$ the Beginning of the Irrigation Period (BIP). The percentages $P_{\min 1}$ and $P_{\min 2}$ are reffered to their own period (i.e before and after BIP, respectively), and increment of noticeable rainfall episodes $\Delta P_{\min }$ with respect to $P_{\text {min } 1}$ computed as $\left(P_{\min 2}-P_{\min 1}\right) / P_{\min 1}$. MSs and RSs stand for meteorological stations located in the mountains downwind of irrigation land and reference meteorological stations, respectively. ULV and LG mean the Upper and Lower Vegas and the Lower Guadalquivir irrigation lands, respectively. NB and NA stand for the number of meteorological stations with available data used in the analysis before and after the BIP, respectively. Code is the meteorological station identifying letter used in Fig. 1 . Grey shaded cell means that the $\Delta P_{\text {min }}$ variation is positive.

\begin{tabular}{|c|c|c|c|c|c|c|c|c|c|c|c|}
\hline & \multirow[b]{2}{*}{ Code } & \multirow[b]{2}{*}{ (NB/NA) } & \multicolumn{3}{|c|}{$P_{\min 1}(\%)$} & \multicolumn{3}{|c|}{$P_{\min 2}(\%)$} & \multicolumn{3}{|c|}{$\Delta P_{\min }(\%)=\left(P_{\min 2}-P_{\min 1}\right) / P_{\min 1}$} \\
\hline & & & June & July & August & June & July & August & June & July & August \\
\hline \multicolumn{12}{|l|}{ ULV MSs } \\
\hline Barcarrota & $\mathrm{A}$ & $(24 / 37)$ & 60.0 & 12.0 & 36.0 & 91.8 & 35.1 & 54.0 & $53.0 \%$ & $192.5 \%$ & $50.0 \%$ \\
\hline Cabeza del Buey & $\mathrm{B}$ & $(25 / 35)$ & 80.0 & 45.0 & 40.0 & 62.3 & 40.0 & 40.1 & $-22.1 \%$ & $-11.1 \%$ & $0.3 \%$ \\
\hline Fregenal de la Sierra & $\mathrm{C}$ & $(17 / 38)$ & 70.5 & 23.5 & 35.2 & 84.8 & 33.3 & 45.4 & $20.3 \%$ & $41.7 \%$ & $29.0 \%$ \\
\hline Helechal & $\mathrm{D}$ & $(14 / 34)$ & 86.6 & 13.3 & 13.3 & 90.9 & 47.0 & 41.1 & $5.0 \%$ & $253.4 \%$ & $209.0 \%$ \\
\hline Los Santos de Maimona & $\mathrm{E}$ & $(19 / 34)$ & 66.6 & 27.7 & 27.7 & 84.8 & 42.4 & 30.3 & $27.3 \%$ & $53.1 \%$ & $9.4 \%$ \\
\hline Malpartida de la Serena & $\mathrm{F}$ & $(14 / 38)$ & 71.4 & 14.2 & 21.4 & 81.5 & 36.8 & 47.3 & $14.1 \%$ & $159.2 \%$ & $121.0 \%$ \\
\hline Monterrubio de la Serena & $\mathrm{G}$ & $(14 / 39)$ & 69.2 & 30.7 & 23.0 & 84.2 & 39.4 & 42.1 & $21.7 \%$ & $28.3 \%$ & $83.0 \%$ \\
\hline Puerto Hurraco & $\mathrm{H}$ & $(20 / 38)$ & 73.6 & 42.1 & 42.1 & 89.4 & 36.8 & 52.6 & $21.5 \%$ & $-12.6 \%$ & $24.9 \%$ \\
\hline Valle Serena & $\mathrm{I}$ & $(14 / 39)$ & 84.6 & 15.3 & 30.7 & 73.6 & 36.8 & 44.7 & $-13.0 \%$ & $140.5 \%$ & $45.6 \%$ \\
\hline Valverde de Llerena & $\mathrm{J}$ & $(18 / 37)$ & 70.5 & 23.5 & 35.2 & 78.3 & 29.7 & 37.8 & $11.1 \%$ & $26.4 \%$ & $7.4 \%$ \\
\hline Monthly Mean value & & & 73.3 & 24.7 & 30.5 & 82.2 & 37.7 & 43.5 & $13.9 \%$ & $87.1 \%$ & $58.0 \%$ \\
\hline \multicolumn{12}{|l|}{ ULV RSs } \\
\hline Badajoz & $\mathrm{K}$ & $(73 / 39)$ & 80.8 & 27.4 & 28.7 & 74.3 & 25.6 & 30.7 & $-8.0 \%$ & $-6.6 \%$ & $7.0 \%$ \\
\hline Usagre & $\mathrm{L}$ & $(23 / 39)$ & 68.9 & 41.3 & 48.2 & 73.6 & 39.4 & 44.7 & $6.8 \%$ & $-4.6 \%$ & $-7.3 \%$ \\
\hline Monthly Mean value & & & 74.9 & 34.4 & 38.5 & 74.0 & 32.5 & 37.7 & $-0.6 \%$ & $-5.6 \%$ & $-0.1 \%$ \\
\hline \multicolumn{12}{|l|}{ LG MSs } \\
\hline Bélmez & a & $(26 / 28)$ & 76.9 & 19.2 & 20.8 & 80.0 & 29.0 & 40.0 & $4.0 \%$ & $51.0 \%$ & $92.3 \%$ \\
\hline Espiel & $\mathrm{b}$ & $(24 / 29)$ & 79.1 & 13.0 & 40.0 & 75.0 & 45.1 & 45.1 & $-5.2 \%$ & $246.9 \%$ & $12.8 \%$ \\
\hline Fuenteobejuna & $\mathrm{c}$ & $(26 / 31)$ & 80.7 & 8.3 & 34.7 & 77.4 & 35.4 & 48.3 & $-4.1 \%$ & $326.5 \%$ & $39.2 \%$ \\
\hline Hinojosa del Duque & $\mathrm{d}$ & $(28 / 28)$ & 75.0 & 28.2 & 42.8 & 85.7 & 39.2 & 50.0 & $14.3 \%$ & $39.0 \%$ & $16.8 \%$ \\
\hline Pantano Guadalmellato & $\mathrm{e}$ & $(56 / 23)$ & 57.8 & 12.5 & 19.6 & 60.8 & 30.4 & 30.4 & $5.2 \%$ & $143.2 \%$ & $55.1 \%$ \\
\hline Peñarroya & $\mathrm{f}$ & $(53 / 9)$ & 71.7 & 28.3 & 35.8 & 44.4 & 22.2 & 44.4 & $-38.1 \%$ & $-21.6 \%$ & $24.0 \%$ \\
\hline Pozoblanco & g & $(48 / 29)$ & 77.1 & 27.1 & 41.6 & 82.7 & 48.2 & 51.7 & $7.3 \%$ & $77.9 \%$ & $24.3 \%$ \\
\hline Monthly Mean value & & & 74.0 & 19.5 & 33.6 & 72.3 & 35.6 & 44.3 & $-2.4 \%$ & $123.3 \%$ & $37.8 \%$ \\
\hline \multicolumn{12}{|l|}{ LG RSs } \\
\hline Córdoba & $\mathrm{h}$ & $(15 / 23)$ & 83.3 & 25.0 & 16.6 & 73.3 & 16.6 & 26.6 & $-12.0 \%$ & $-33.6 \%$ & $60.2 \%$ \\
\hline San Fernando & $\mathrm{i}$ & $(108 / 23)$ & 75.9 & 10.1 & 18.5 & 65.2 & 0.0 & 17.4 & $-14.1 \%$ & $-100.0 \%$ & $-5.9 \%$ \\
\hline Sevilla & $\mathrm{j}$ & $(23 / 27)$ & 82.6 & 4.0 & 21.7 & 59.2 & 11.1 & 22.2 & $-28.3 \%$ & $177.5 \%$ & $2.3 \%$ \\
\hline Monthly Mean value & & & 80.6 & 13.0 & 18.9 & 65.9 & 9.2 & 22.1 & $-18.1 \%$ & $14.6 \%$ & $18.9 \%$ \\
\hline
\end{tabular}

mean summertime difference $\langle\Delta P\rangle$ is $4 \mathrm{~mm} /$ month in ULV, and $2.6 \mathrm{~mm} / \mathrm{month}$ in LG. The ratio of these two increases is roughly proportional to the volume of water applied for irrigation. While these numbers are relatively small, $\langle\Delta P\rangle$ represents mean summertime increases of $82 \%$ at ULV and $80 \%$ at $\mathrm{LG}$.

In the reference stations $\Delta P$ behaves differently, showing mean summertime decreases of $2.3 \mathrm{~mm}$ in both study zones corresponding to decreases in $\langle\Delta P\rangle$ of $20 \%$ and $32 \%$ in ULV and $L G$, respectively.

The ratio of monthly to annual precipitation, $\Delta r$, at MSs in ULV and LG increases in $86 \%$ and $76 \%$ of cases, respectively (Table 2). Increments are larger in June and July than in August. The average increase during summer months, $\langle\Delta r\rangle$ is $1 \%$ in ULV and $0.7 \%$ in LG. Again, while these values are small, they represent an increase of $87 \%$ and $125 \%$, respectively, with respect to the situation prior to irrigation. In short, summer rainfall is also increasing relative to the mean annual precipitation. As a result, summer has become wetter at MSs after the beginning of irrigation. Instead, RSs display a negligible decrease in $\langle\Delta r\rangle$ in both irrigation lands (i.e., ULV and LG).

The statistic $\Delta P_{\min }$ investigates whether the irrigation increases the frequency of noticeable rainfall episodes (i.e., events with precipitation above $2 \mathrm{~mm}$ ). To obtain $\Delta P_{\min }$ we first compute $P_{\min 1}$ and $P_{\min 2}$ (Table 3) as the percentage of noticeable rainfall episodes in each period (i.e., before and after the irrigation transition time), and then $\Delta P_{\min }$ is computed as $\left(P_{\min 2}-P_{\min 1}\right) / P_{\min 1}$. Table 3 shows positive $\Delta P_{\min }$ at MSs in $83 \%$ and $85 \%$ of cases at ULV and LG, 
respectively. As can be shown, there are a number of positive increments with statistically significance after the beginning of the irrigation period, that are observed in June and July, but also in August. The mean summertime $\left\langle\Delta P_{\min }\right\rangle$ is $11.6 \%$ in ULV and $8.3 \%$ in LG, that correspond to $\left\langle\Delta P_{\min }\right\rangle=53 \%$ in both irrigated lands.

The results indicate that the positive variation in $\Delta P$ during the summer results from a net increase in the number of noticeable rainfall events, rather than from sporadic large rainfall episodes.

It is unclear whether the decrease in rainfall at RSs is mechanistically linked to the increase at MSs. On one hand, the vertical fluxes associated to evaporation might cause a reduction in rainfall at the valleys. On the other, the net addition of moisture to the air might have been expected to cause a generalized increase in rainfall, which was indeed the point made by Barnston and Schickedanz (1984). The fact is that significant decreases in rainfall during the second half of the XXth century have been reported for both the Guadalquivir and Guadiana basins by Ayala-Carcedo (1996) and EstebanParra et al. (1998). They linked the basin-wide decrease in rainfall to global climate change.

\section{Conclusions}

Irrigation impacts rainfall at the basin scale, causing an increase in precipitation at the adjacent mountains located downwind of the Upper and Lower Vegas (ULV) and Lower Guadalquivir irrigation lands. In the case of ULV the mean differences in precipitation are $8.3 \mathrm{~mm}$ (43\% increase), $3.5 \mathrm{~mm}(170 \%)$ and $0.2 \mathrm{~mm}(32 \%)$ for June, July and August, respectively. In the case of LG the mean increases are $3.2 \mathrm{~mm}(14 \%), 3.7 \mathrm{~mm}(196 \%)$ and $0.9 \mathrm{~mm}(29 \%)$. Increments in precipitation have greater statistical significance in June and July than in August. The fraction of summer to annual precipitation has also increased at the downwind mountains after the onset of irrigation. The increase also displays greater statistical significance in June and July than in August.

Summers at the mountains downwind the irrigation lands have become wetter not only in terms of total rainfall, but also in terms of number of events with noticeable rainfall. The increases at ULV are $14 \%, 87 \%$ and $58 \%$ for June, July and August, respectively. In the case of LG the same monthly mean $\Delta P_{\min }$ variations are $-2 \%, 123 \%$ and $37.8 \%$. The joint positive variation in $\Delta P$ and $\Delta P_{\min }$ after the beginning of irrigation points that the increase in rainfall is not caused by sporadic heavy storms, but by an increase of the number of rainfall events during the summer.

The increase in rainfall is distributed over a broad region. Therefore, it is not sufficient to generate runoff and increase available water resources. However, it is sufficient to increase the specific weight of summer precipitation with respect to the other seasons. Moreover, it may help increase the range of shrubs and other small plants that survive the otherwise arid summers of these mountains.

Modelling studies generally predict that irrigation causes an increase in rainfall due to the soil moisture-atmosphere interaction. Our analysis supports those findings, but does not elucidate the small scale mechanisms of the feedback, which should be the subject of site specific models. In this regard, it is relevant to point that we have obtained mean variations of rainfall (both $\Delta P$ and $\Delta r$ ) in MSs that are proportional to the mean annual water volume applied in the neighbouring upwind irrigation lands. This result might help to reduce the modelling uncertainty in the simulated strength of the irrigation-rainfall feedback (Guo et al., 2006), and lends support to climate models, whose credibility is a controversial issue in itself (Koutsoyiannis et al., 2009).

The different trend observed in MSs and RSs for the three selected statistics, reveals that irrigation-precipitation feedback may locally induce rainfall in-homogeneities inside a given synoptic rainfall/climate trend. It should be noted that the values of the statistics from the reference weather stations decreased. Such behaviour, throughout southern Spain, has been regarded by Ayala-Carcedo (1996) and Esteban-Parra et al. (1998) as an early warning of the predicted climate change.

Acknowledgements. This research was undertaken as part of the European Union (FP6) funded Integrated Project called WATCH through contract number 036946. The meteorological data have been provided by the Spanish state meteorological agency (AEMET). Comments by B. van den Hurk, R. W. A. Hutjes and an anonymous referee are gratefully acknowledged.

Edited by: B. van den Hurk

\section{References}

Ayala-Carcedo, F. J.: Reducción de los recursos hídricos en España por el posible cambio climático, Tecno ambiente, ISSN 11334665, 64, 43-48, 1996.

Barnston, A. G. and Schickedanz, P. T.: The effect of irrigation on warm season precipitation in the southern Great Plains, J. Clim. Appl. Meteorol., 23, 865-888, 1984.

Boucher, O., Myhre, G., and Myhre, A.: Direct human influence of irrigation on atmospheric water vapour and climate, Clim. Dynam., 22, 597-603, doi:10.1007/s00382-004-0402-4, 2004.

Eltahir, E. A. B.: A soil moisture-rainfall feedback mechanism 1. Theory and observations, Water Resour. Res., 34(4), 765-776, 1998.

Esteban-Parra, M. J., Rodrigo, F. S., and Castro-Diez, Y.: Spatial and temporal patterns of precipitation in Spain for the period 1880-1992, Int. J. Climatol., 18, 1557-1574, 1998.

Font, I. and I. N. M. (Instituto Nacional de Meteorología): Atlas climático de España, Eds. Ministerio de Transportes-Turismo y Comunicaciones and I. N. M., Madrid, 43 pp., 1983.

Fowler, W. B. and Helvey, J. D.: Irrigation increases rainfall? (response), Science, 188, 281, 1975. 
Giorgi, F., Mearns, L. O., Shields, C., and Mayer, L.: A regional model study of the importance of local versus remote controls of the 1988 drought and the 1993 flood over the central United States, J. Climate, 9, 1150-1161, 1996.

Guo, Z., Dirmeyer, P. A., Koster, R. D., Bonan, G., Chan, E., Cox, P., Gordon, C. T., Kanae, S., Kowalczyk, E., Lawrence, D., Liu, P., Lu, C. H., Malyshev, S., Mcavaney, B., Mcgregor, J. L., Mitchell, K., Mocko, D., Oki, T., Oleson, K. W., Pitman, A., Sud, Y. C., Taylor, C. M., Verseghy, D., Vasic, R., Xue, Y., and Yamada, T.: GLACE: The Global Land-Atmosphere Coupling Experiment, Part II: Analysis, J. Hydrometeorol., 7, 611-625, 2006.

Koster, R. D., Dirmeyer, P. A., Guo, Z., Bonan, G., Chan, E., Cox, P., Gordon, C. T., Kanae, S., Kowalczyk, E., Lawrence, D., Liu, P., Lu, C. H., Malyshev, S., McAvaney, B., Mitchell, K., Mocko, D., Oki, T., Oleson, K., Pitman, A., Sud, Y. C., Taylor, C. M., Verseghy, D., Vasic, R., Xue, Y., and Yamada, T.: Regions of strong coupling between soil moisture and precipitation, Science, 305, 1138-1140, doi:10.1126/science.1100217, 2004.

Koster, R. D., Guo, Z.-C., Dirmeyer, P. A., Bonan, G., Chan, E., Cox, P., Gordon, C. T., Kanae, S., Kowalczyk, E., Lawrence, D., Liu, P., Lu, C.-H., Malyshev, S., McAvaney, B., Mitchell, K., Mocko, D., Oki, T., Oleson, K., Pitman, A., Sud, Y. C., Taylor, C. M., Verseghy, D., Vasic, R., Xue, Y., and Yamada, T.: GLACE: The Global Land-Atmosphere Coupling Experiment: Part 1: Overview, J. Hydrometeorol., 7, 590-610, doi:10.1175/JHM510.1, 2006.

Koutsoyiannis, D., Makropoulos, C., Langousis, A., Baki, S., Efstratiadis, A., Christofides, A., Karavokiros, G., and Mamassis, N.: HESS Opinions: "Climate, hydrology, energy, water: recognizing uncertainty and seeking sustainability", Hydrol. Earth Syst. Sci., 13, 247-257, doi:10.5194/hess-13-247-2009, 2009.

Lin, Y. L., Chiao, S., Wang, T. A., Kaplan, M. L., and Weglarz, R. P.: Some common ingredients of heavy orographic rainfall, Weather Forecast., 16, 633-660, 2001.
Moore, D. S.: The Basic Practice of Statistics, W. H. Freeman and Co., New York, 1995.

Moore, N. and Rojstaczer, S.: Irrigation-induced rainfall and the Great Plains, J. Appl. Meteorol., 40, 1297-1309, 2001.

Moore, N. and Rojstaczer, S.: Irrigation's Influence on Precipitation: Texas High Plains, U.S.A., Geophys. Res. Lett., 29(16), 1755, doi:10.1029/2002GL014940, 2002.

O'Mahony, M.: Sensory Evaluation of Food: Statistical Methods and Procedures, CRC Press, New York, 492 pp., 1986.

Paegle, J., Nogues-Paegle, J., and Mo, K. C.: Dependence of simulated precipitation on surface evaporation during the 1993 United States summer floods, Mon. Weather. Rev., 124, 345-361, 1996.

Pielke Sr., R. A., Adegoke, J., Beltran-Przekurat, A., Hiemstra, C. A., Lin, J., Nair, U. S., Niyogi, D., and Nobis, T. E.: An overview of regional land-use and land-cover impacts on rainfall, Tellus B, 59, 587-601, 2007.

Robinson, E.: Dispersion and fade of atmospheric pollutants, in: Air Pollution and Plant Life, edited by: Treshow, M., Wiley, New York, 15-37, 1884.

Smith, R. B.: The influence of mountains on the atmosphere, Academic Press, Adv. Geophys., 21, 87-230, 1979.

Smith, R. B., Paegle, J., Clark, T., Cotton, W., Forbes, G., McGinley, J., Pan, H. L., and Ralph, M.: Local and remote effects of mountains on weather: Research needs and opportunities, B. Am. Meteorol. Soc., 78, 877-892, 1997.

Spiegel, M. and Stephens, L.: Schaum's outlines, "Statistics” Third Edition, McGraw-Hill, New York, 538 pp., 1999.

Stidd, C. K., Fowler, W. B., and Helvey, J. D.: Irrigation increases rainfall?, Science, 188(4185), 279-280, 1975.

Zheng, X. and Eltahir, E. A. B.: A soil moisture-rainfall feedback mechanism 2. Numerical experiments, Water Resour. Res., 34(4), 777-785, 1998. 